\title{
Properties Characterization of Napier Grass (Pennisetum Purpureum) as the Non-wood Substitution for Natural Fiber Papermaking
}

\author{
Hooi Peng Lim ${ }^{*}$, Wan Aizan Wan Abdul Rahman ${ }^{2}$, Jiun Hor Low \\ ${ }^{1}$ Department of Mechanical Engineering, Politeknik Kota Kinabalu \\ No. 4, Jalan Politeknik, KKIP Barat, Kota Kinabalu Industrial Park, Kota Kinabalu Sabah, 88460, MALAYSIA \\ ${ }^{2}$ Department of Polymer Engineering, \\ Universiti Teknologi Malaysia, Skudai Johor, 81310, MALAYSIA \\ ${ }^{3}$ School of Engineering, Taylor's University, \\ Taylor's Lakeside Campus, No. 1 Jalan Taylor's, Subang Jaya Selangor, 47500, MALAYSIA
}

DOI: https://doi.org/10.30880/jamea.2020.01.01.004

Received 25th October 2020; Accepted 10th February 2020; Available online 29th February 2020

\begin{abstract}
Napier grass, scientifically known as pennisetum purpureum is esteemed for its high productivity, robust perennial nature and pest resistance characteristics. This perennial tropical grass has versatile harvesting period and vegetative propagation through stem cutting provide it an excellent fiber reserve. Numerous preliminary studies on properties characterization of napier grass were indicated in the literature, however, a comprehensive and in-depth analysis of using this tropical grass as non-wood substitution for paper is relatively underexplored. Therefore, the primary purpose of the present study is to explore the potential of using napier grass as the non-wood substitution for greener paper making. In general, the fibre length of napier grass at approximately $20 \mu \mathrm{m}$ which is similar to the short fiber hardwoods, provides an idea of the potential usefulness of these naturally uncultivated crops in pulp and paper making. The present study indicates that the treated $4 \% \mathrm{NaOH}$ leave fibre samples is significant for the replacement of wood based paper due to their lower moisture uptake, better shear strength, higher tensile stress and uniformly distribution of fibers. Alternatively, this new approach demonstrates the feasibility of using napier grass as the nonwood substitute for lignocellulosic rich paper making.
\end{abstract}

Keywords: Napier grass, non-wood substitute, pennisetum purpureum, lignocellulosic

\section{Introduction}

Driven by the significant forest degradation for pulp and paper mills globally, an alternative to replace hardwoods by non-wood lignocellulosic and recyclable fiber resources has been explored since 1990. These non-wood fibers are lavishly available from agricultural residues, industrial crops, and natural growing plants which are complicated structures with the content of $\alpha$-cellulose, hemicellulose and lignin in nature. Numerous research studies were conducted to investigate the comparative properties of grasses and agricultural residues to the wood-based pulp and paper sheets. The shorter growth cycles, lower lignin content, moderate fertilization and irrigation demand of these non-wood plants have reduced the use of energy consumption during the pulping process for cellulose and noncellulosic substances separation. Apparently, fast-growing perennial plants extracted by Soda-AQ and Kraft pulping methods have been identified with high bleach-ability and comparative yield strength as well as viscosity to wood- 
based paper sheets [1]. In addition, it is reported that the chemical composition of Napier grass fibers fertilized by municipal sewage sludge (MSS) reveals with an increasing growth time of the fertilizing treatment, the content of holocellulose is increased. Higher content of these cellulose content could gain greater paper quality due to the present of pentosan chemical substances which have effectively inhibited the irreversible pore closure of fibers [2]. Pulp extraction of natural grasses by chlorination and alkaline treatment indicated higher cellulose content, lower lignin and hemicelluloses content [3][4][5]. Nevertheless, results reported by Madakadze et al. show the non-wood plants could be easily pulped with the conventional Kraft pulping process where the pulping yields at $49 \%$ on average with kappa numbers of $12.3 \%$, respectively [6]. Alternatively, the newly developed paper sheet developed by kenaf fiber incorporated with polyaniline coated kenaf pulp (KF/ KF-PANI) revealed to be electrically conductive with a percolation concentration at $25 \mathrm{wt} \%$ of KF-PANI [7]. Additionally, natural fibers treated with $2-5 \mathrm{wt} \%$ alkaline solution were found to retain the crystalline structure and thus enhancing the strength of the fibers [8]. Removal of weak amorphous elements on the Napier fibers by alkaline treatment considerably reduces the hemicellulose content with increasing of alkali percentage in the solution. Hemicellulose is a matrix of polysaccharides, which is also known as heteropolymers and exhibits structure of amorphous in random order. Fibrils of Napier grass after subjecting to alkaline treatment have become more capable of rearranging themselves in an orderly compact form. This formation leads to a closer packing manner of the fibrils and subsequently improves the Napier fiber strength. A study on alkaline and biotreatment with P. Sajor-caju treatments have confirmed that alkaline treatment is more effective in promoting delignification and enhancing the biodigestibility of Napier grass [9]. Nevertheless, the alkaline treated Napier grass is less susceptible to water penetration due to the contraction of cellulose walls and the decrease of fiber volume fraction [10]. Reduction in water uptake could avoid the deterioration between the fibrils bonding. It is therefore essential to explore for alternative non-wood plants as the substitution for natural fiber papermaking. Despite of alkaline solutions having favorable hydroxyl ions that can solubilize hemicellulose and enrich cellulose of the fibers, its effects on Napier grass leaves and stem pulping are still unknown. Hence, the present study aims to present the effects of sodium hydroxide $(\mathrm{NaOH})$ treatment on tear index, tensile strength, moisture absorption and surface morphology of Napier grass leaves and stem respectively.

\section{Materials and Methods}

\subsection{Materials}

Napier grass, also known as elephant grass is a perennial fibrous grass with small height stems, long and slender leaves without branches. It is a species from the Poaceae family of Pennisetum Purpureum Schum with promising nature of easy cultivation, rapid growth and abundantly available in tropical regions with a little supplement of nutrients [11]. Their harvest period is three to four months after sowing and able to grow at an interval of six to eight weeks for up to five years continuously. The Napier grass fibers yield was reported at 40 percent from each clump plant and achieved 40 tons of biomass yield per hectare annually [12]. Table 1 indicates the properties of Napier grass.

Table 1 - Chemical, physical and mechanical properties for napier grass [13]

\begin{tabular}{|c|c|c|c|c|c|c|c|c|}
\hline \multirow[t]{2}{*}{ Material } & \multicolumn{3}{|c|}{ Chemical properties } & \multicolumn{2}{|c|}{ Physical properties } & \multicolumn{3}{|c|}{ Mechanical properties } \\
\hline & $\begin{array}{c}\text { Cellulose, } \\
w / w \%\end{array}$ & $\begin{array}{c}\text { Hemicelluloses, } \\
w / w \%\end{array}$ & $\begin{array}{l}\text { Lignin, } \\
w / w \%\end{array}$ & $\begin{array}{c}\text { Fibre } \\
\text { length, } \\
\mathrm{mm}\end{array}$ & $\begin{array}{c}\text { Fibre } \\
\text { diameter, } \\
\mathrm{mm}\end{array}$ & $\begin{array}{c}\text { Tensile } \\
\text { index, } \\
m N / g\end{array}$ & $\begin{array}{c}\text { Tear } \\
\text { index, } \\
m N . m^{2} / g\end{array}$ & $\begin{array}{c}\text { Burst } \\
\text { index, } \\
\text { kPa.m } \mathrm{m}^{2} / \mathrm{g}\end{array}$ \\
\hline Napier grass & 45.60 & 30.50 & 17.70 & 0.75 & 15.14 & 93.25 & 4.40 & 5.85 \\
\hline
\end{tabular}

\subsection{Pulping and alkaline treatment of the fibers}

In the present study, the collected Napier grass was washed with distilled water to remove debris and suspended impurities and air-dried for up to 24 hours. The dried Napier grass was separated into leaves and stems and manually cut in size of $0.5-1 \mathrm{~cm}$ for pulping. Alkaline treatment was carried out for samples weighted 300 grams, at interval charge of sodium hydroxide $(\mathrm{NaOH})$ from $1 \%$ to $5 \%$ mixing in $3500 \mathrm{ml}$ distilled water and a temperature of $100^{\circ} \mathrm{C}$ for 30 minutes. The treated fibers were then washed and filtered out for paper sheet making. Samples prepared in the present study were labeled in Table 2 . 
Table 2 - Label for samples

\begin{tabular}{ccc}
\hline NaOH charge percentage & Napier grass leave & Napier grass stem \\
\hline $1 \%$ & $\mathrm{NaOH} 1 \mathrm{~L}$ & $\mathrm{NaOH} 1 \mathrm{~S}$ \\
$2 \%$ & $\mathrm{NaOH} 2 \mathrm{~L}$ & $\mathrm{NaOH} 2 \mathrm{~S}$ \\
$3 \%$ & $\mathrm{NaOH} 3 \mathrm{~L}$ & $\mathrm{NaOH} 3 \mathrm{~S}$ \\
$4 \%$ & $\mathrm{NaOH} 4 \mathrm{~L}$ & $\mathrm{NaOH} 4 \mathrm{~S}$ \\
$5 \%$ & $\mathrm{NaOH} 5 \mathrm{~L}$ & $\mathrm{NaOH} 5 \mathrm{~S}$ \\
\hline
\end{tabular}

\subsection{Preparation of Paper Sheet}

The paper sheet was made with a basis weight of $62 \mathrm{~g} / \mathrm{m}^{2}$, using standard sheet former. Preparation of paper sheet started with tossing, blending, screening, drying and finally compressing of pulp. The tossed pulp was disintegrated in a laboratory blender until it was soft and diluted. The blended pulp was poured into a wire screen mold with a dimension of $210 \mathrm{~mm} \times 297 \mathrm{~mm}$ in a basin filled with water. After settling of pulp, water was drained by dispersing the pulp uniformly to form a paper sheet. The sheet was sun-dried and compressed prior to further testing.

\subsection{Characterization}

Tear test was conducted to indicate the tear index of the leave and stem sheet samples using the Elmendorf Tear Method (ASTM D-1922). The average of five samples was prepared for each percentage of $\mathrm{NaOH}$ treatment accordingly and dried at $60^{\circ} \mathrm{C}$ for 24 hours prior to the testing. The tear index of the paper sheet is indicated in equation $(1)$.

$$
\text { Tear index }=\frac{\text { Average tearing force }(\mathrm{mN})}{\text { Average grammage }\left(\mathrm{g} / \mathrm{m}^{2}\right)}
$$

Where the average tearing force is indicated in Equation (2),

$$
\text { Average tearing force }(\mathrm{mN})=\frac{16 \times 9.81 \times \text { average scale reading }}{\text { Number of layers }}
$$

Additionally, a moisture absorption test (ASTM D3285) was conducted to determine the amount of water absorbed under a specific condition. Factors that affect the moisture uptake include the type of material, additives, temperature and length of exposure. Samples were first weighted at intervals of 30 minutes until they were saturated. The equilibrium moisture uptake is calculated in accordance with equation (3).

$$
\text { Moisture absorption }=\frac{W f-W i}{W i} \times 100
$$

Where Wf represents the final weight of the sample and Wi represents the initial weight of the sample. Nevertheless, the tensile test (ASTM D3822) was performed using INSTRON 5982 Universal Testing Machine with a crosshead speed of $1 \mathrm{~mm} / \mathrm{min}$ at ambient temperature with a load cell capacity of $5 \mathrm{kN}$. Samples were cut into $60 \mathrm{~mm}$ length for gripping. Morphology of Napier grass paper sheet was examined using Field Emission Scanning Electron Microscope (FESEM). Images were taken under several magnifications to observe the fiber distribution.

\section{Results and Discussion}

\subsection{Tear Testing (ASTM D-1922)}

Fig. 1(a) and (b) depict the tear index trend of leave fibers and stem samples respectively. The trend of tear index value decreased from $10160 \mathrm{gf}$ to $4430 \mathrm{gf}$ for $1 \% \mathrm{NaOH}$ to $3 \% \mathrm{NaOH}$ treated leave fibers and subsequently increased to $5180 \mathrm{gf}$ at $4 \% \mathrm{NaOH}$ treated leave fibers. However, the results showed a decrease of tear index value to $4480 \mathrm{gf}$ for $5 \% \mathrm{NaOH}$ treated leave fibers. Nevertheless, the tear index value for $1 \% \mathrm{NaOH}$ to $5 \% \mathrm{NaOH}$ treated stem was found to 
decrease dramatically from 19440 gf to $6880 \mathrm{gf}$, accordingly. The lower tear index value for leave fibers is attributed to the mercerization process, which provides a higher crystalline structure compared to the stem. With mercerization via sodium hydroxide $(\mathrm{NaOH})$, the leave fibers became thinner and less rigid. Thereby, cellulose chains of the fibers are able to rearrange themselves uniformly and undergo re-orientation and recrystallization along the direction of the tear. The tear index of the sheets showed a marginal reduction from the control upon mercerization with the concentration of $\mathrm{NaOH}$.

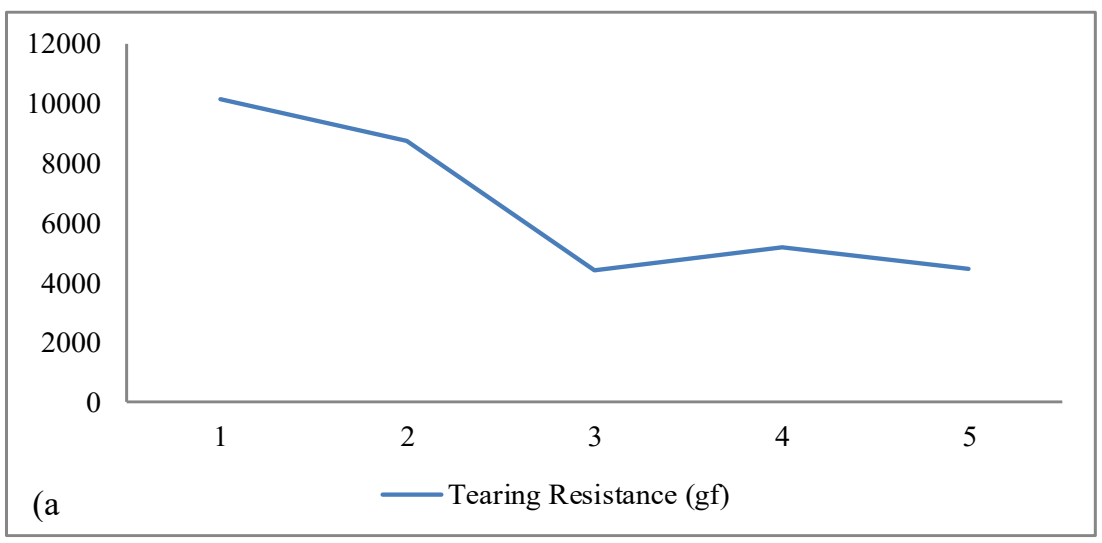

Fig. 1 - (a) Tear index of leave fibers

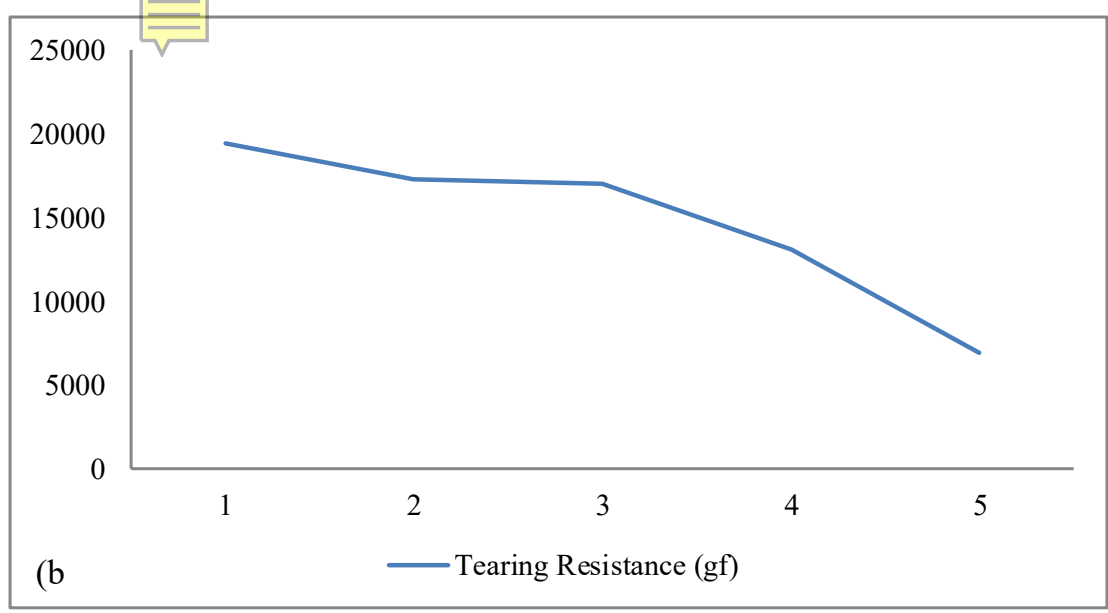

Fig. 1 - (b) Tear index of stem

\subsection{Moisture Absorption Test (ASTM D3285)}

Fig. 2 (a) and (b) indicate that the moisture absorption of all the samples decreases almost linearly with increasing of $\mathrm{NaOH}$ concentration. The optimum moisture uptake in the stem are higher than the cellulosic fiber-based samples (leave fibers) is due to absorbed water molecules in the stem has weakened the intermolecular hydrogen bonding causing in the degradation of interfacial bonding [5]. The lower moisture uptake in leave fibers is attributed to the presence of wax on the surface, which has provided a functional barrier to shield the absorption of water molecules from the surrounding environment. 


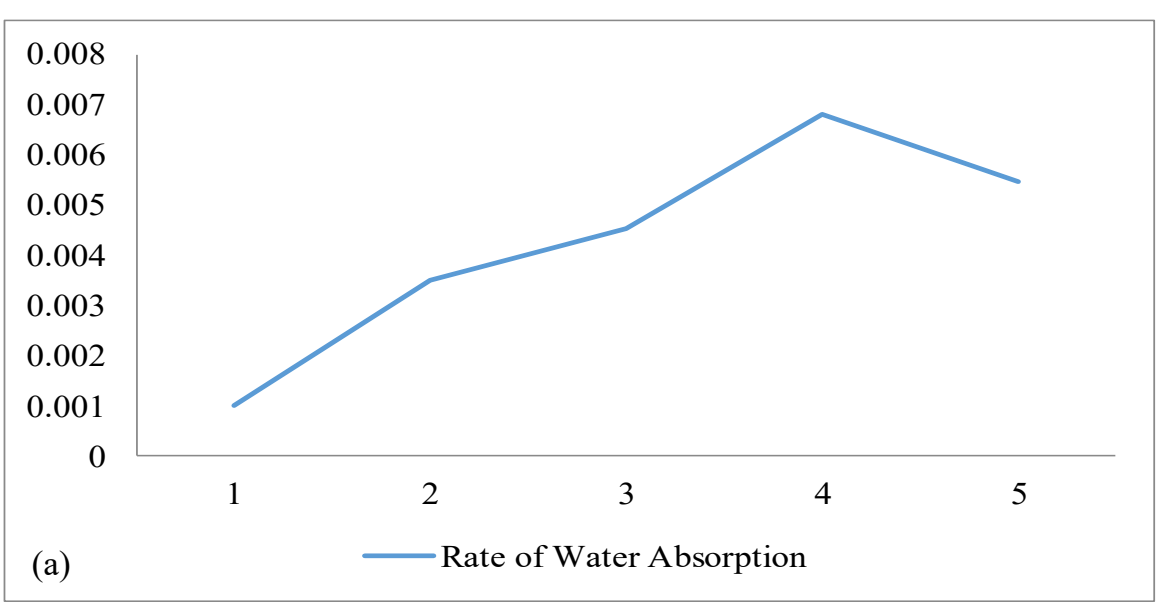

Fig. 2 - (a) Moisture uptake of leave fiber

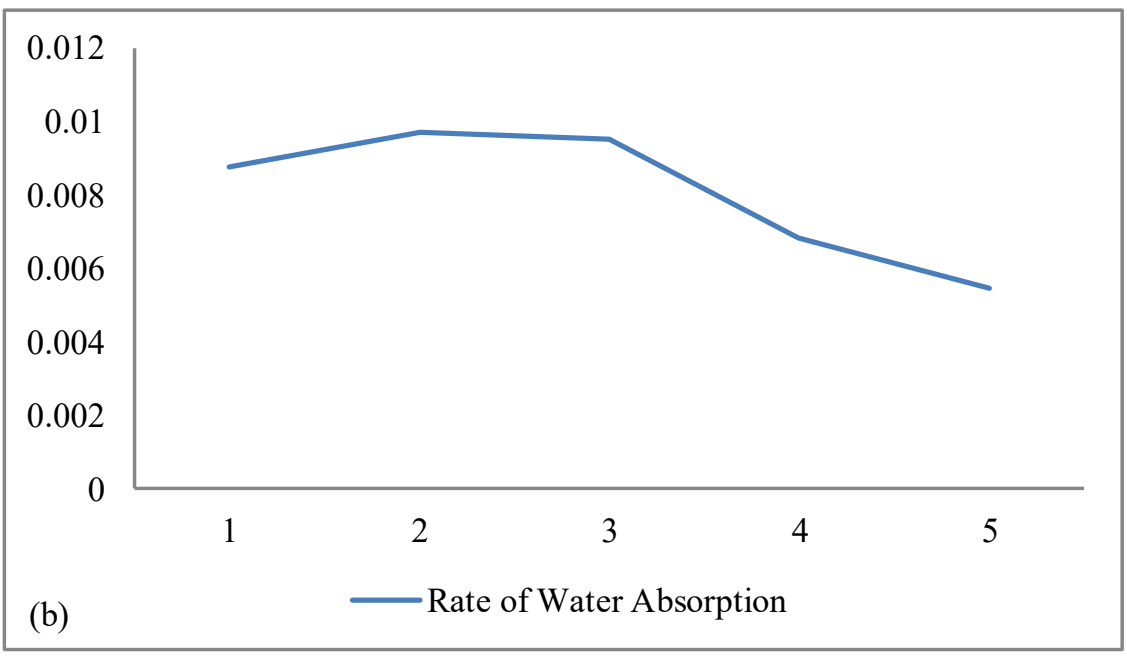

Fig. 2 - (b) Moisture uptake of stem

\subsection{Tensile Test (ASTM D3822)}

The tensile test for treated leave fibers and stem was determined using INSTRON 5982 Universal Testing Machine with a crosshead speed of $1 \mathrm{~mm} / \mathrm{min}$ at ambient temperature with a load cell capacity of $5 \mathrm{kN}$. Maximum stress, modulus and percentage of elongation of the sample were indicated. In each case, three samples were tested and the average value was reported. The tensile properties of the leave fibers and stem are presented in Fig. 3(a) and (b) accordingly. The tensile modulus of treated, $1 \% \mathrm{NaOH}$ to $5 \% \mathrm{NaOH}$ leave fibers were found to be $0.9667 \mathrm{MPa}$, 5.46884 MPa, 7.1734 MPa, 10.7223 MPa and 8.4232 MPa accordingly. Similarly, the maximum stress of the treated, $1 \% \mathrm{NaOH}$ to $5 \% \mathrm{NaOH}$ stem was indicated to be $0.5190 \mathrm{MPa}, 0.8995 \mathrm{MPa}, 1.1563 \mathrm{MPa}, 1.5465 \mathrm{MPa}$ and $2.0933 \mathrm{MPa}$ respectively. It was observed that $4 \% \mathrm{NaOH}$ leave fiber gives the highest tensile stress value at $10.7223 \mathrm{MPa}$. Similar behavior is reported by the other studies [14] in which the presence of hydroxyl ions has solubilized amorphous hemicellulose on $\mathrm{NaOH}$ treatment and enriches the fiber's lignin and hence increase the tensile strength with an increased percentage of $\mathrm{NaOH}$ solution. The tensile modulus of Napier grass leaves was recorded higher than stems is due to the higher degree of structural removal of the amorphous hemicellulose [15]. 


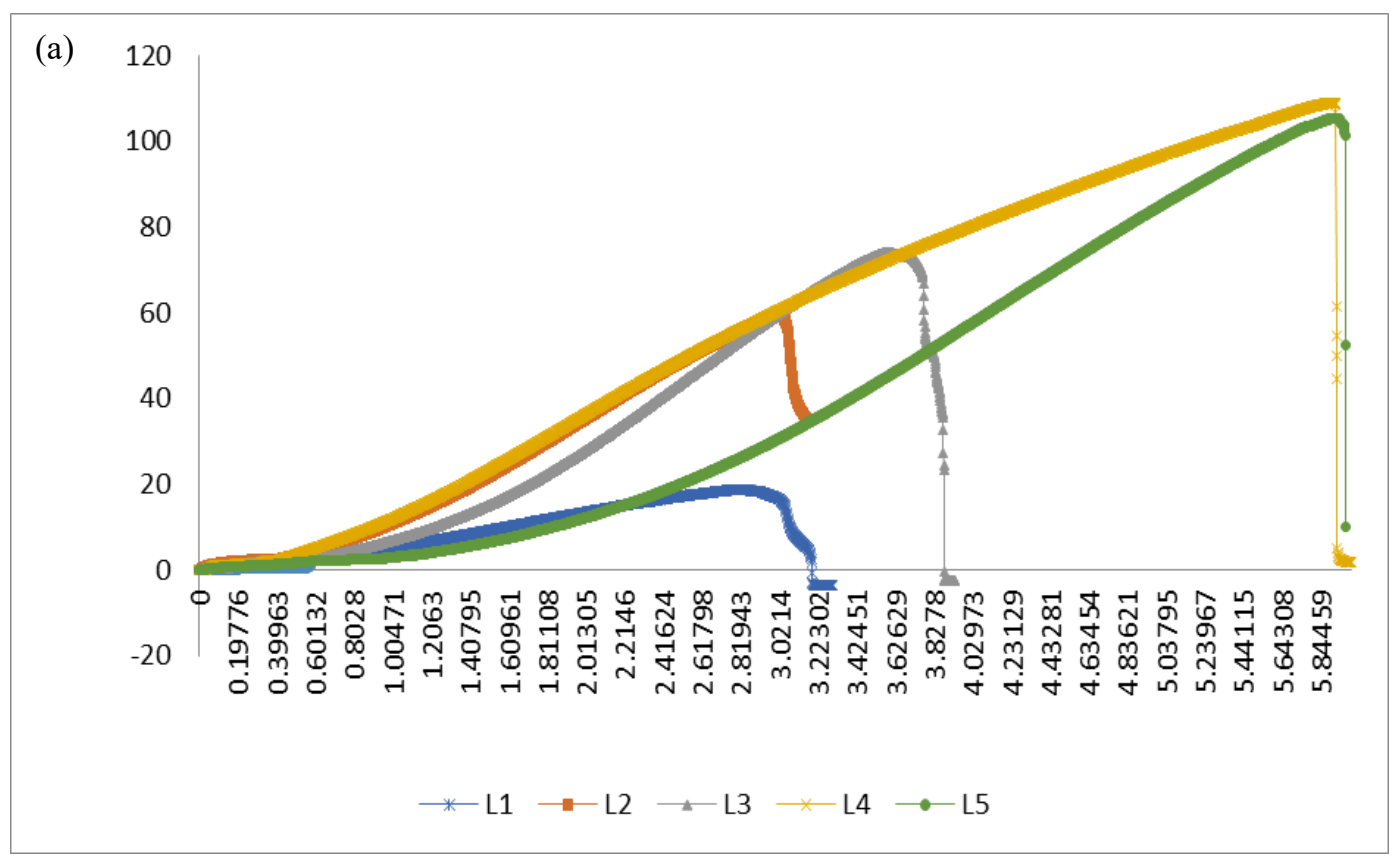

Fig. 3 - (a) Tensile stress of leave fiber

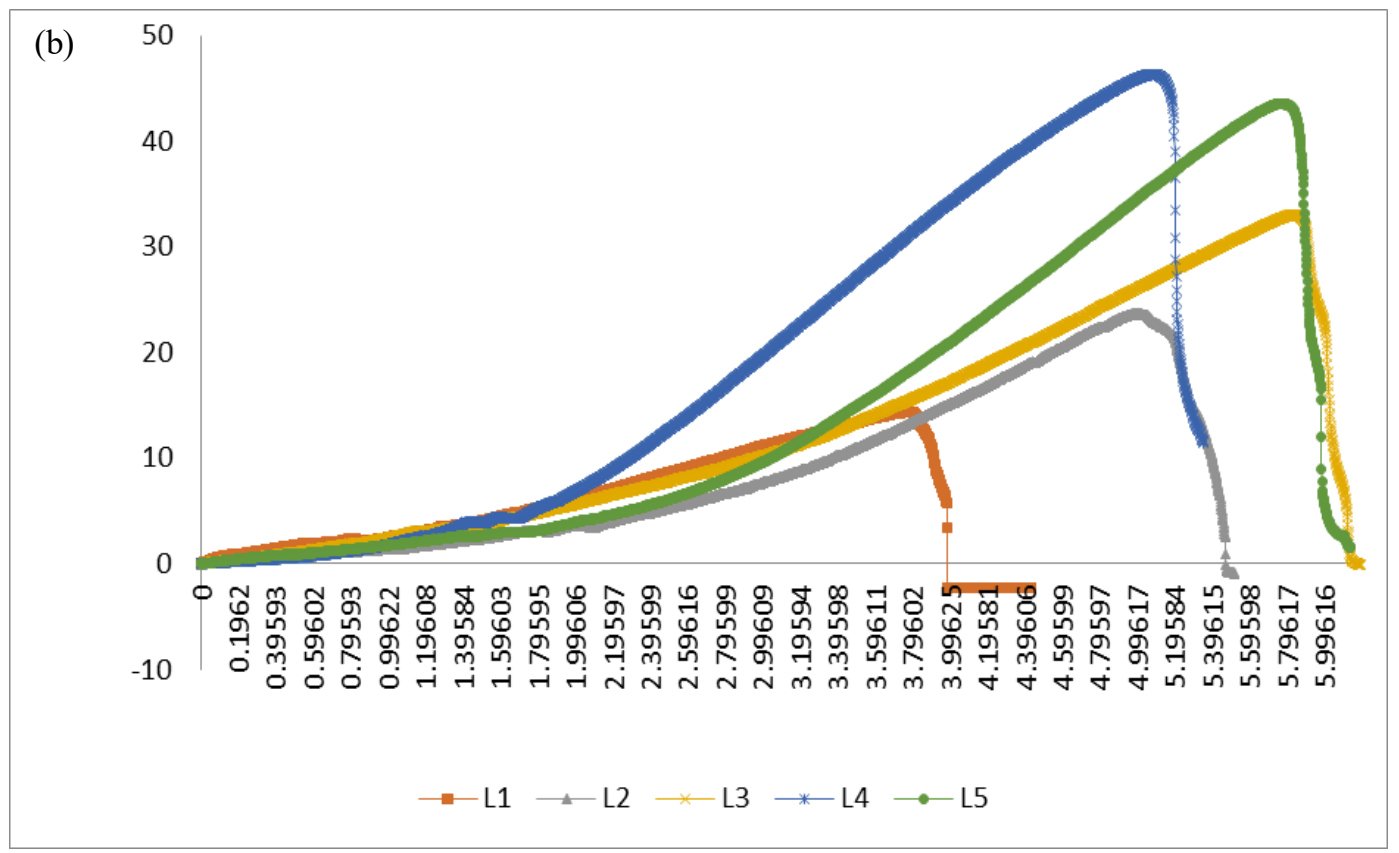

Fig. 3 - (b) Tensile stress of stem

\subsection{FESEM Surface Morphology Characterization}

Field emission scanning electron microscopy (FESEM) is a characterization technique that has been extensively used for morphological inspection. FESEM micrographs indicate the surface morphology for untreated leave fibers and $\mathrm{NaOH}$ treated leave fibers as shown in Fig. 4 (a) and 4 (b) respectively. The fibers were observed to be globular in general. The micrographs of. Fig. 4 (a) illustrates the hemicellulose fibrils before subjecting for alkaline treatment. Untreated leave fibers display a multicellular structure which indicates the porous structure. In general, the bundle of individual cells binds together to form a multi cellulose structure. The hollow cavity called lumen exists inside the unit 
cell of the bio-fibers. The micrograph in Fig. 4(b) indicates that the surface of the fibrils is rougher after alkaline treatment. The percentage of removal of hemicellulose layer is higher when the fraction of alkaline solution is increasing from $1 \% \mathrm{NaOH}$ to $5 \% \mathrm{NaOH}$. The nature of the rougher surface is expected to develop better interfacial bonding among the fibrils in paper sheet making.

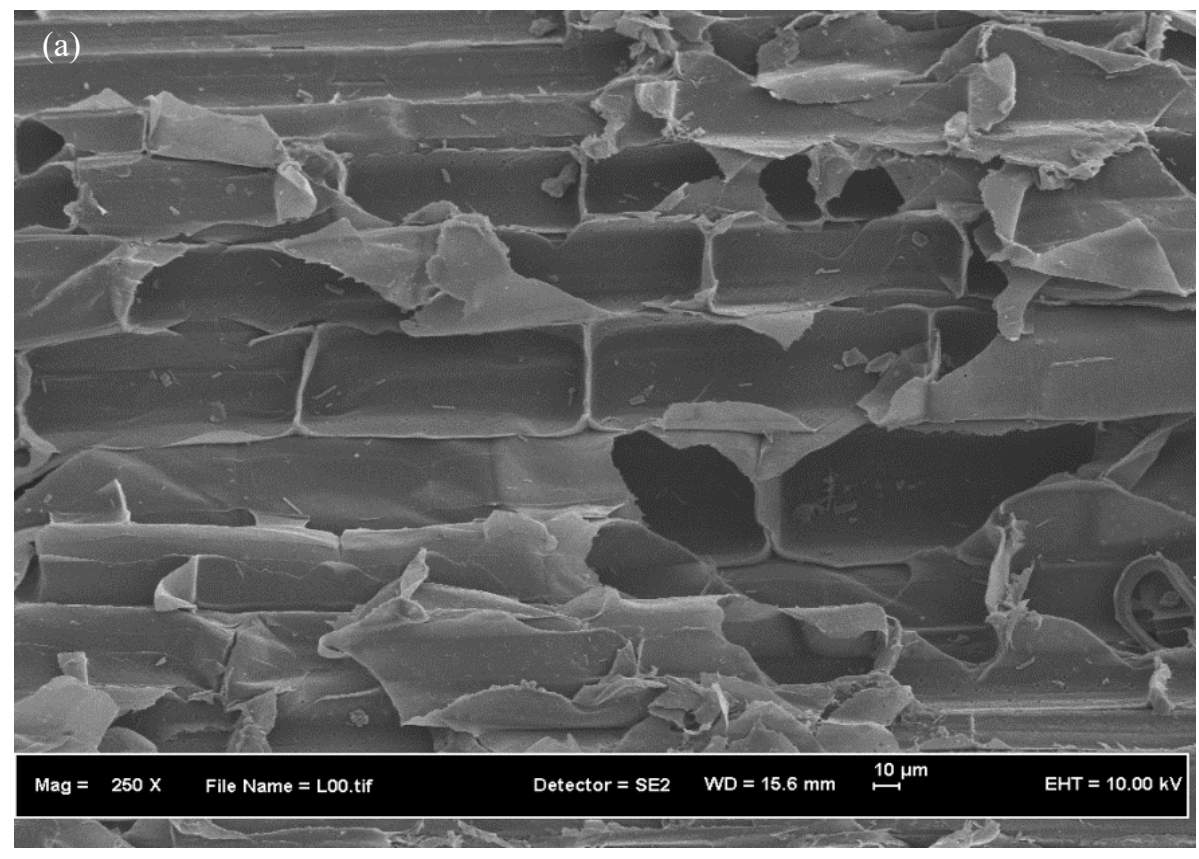

Fig. 4 - (a) Field Emission Scanning Electron micrographs of untreated leave fiber

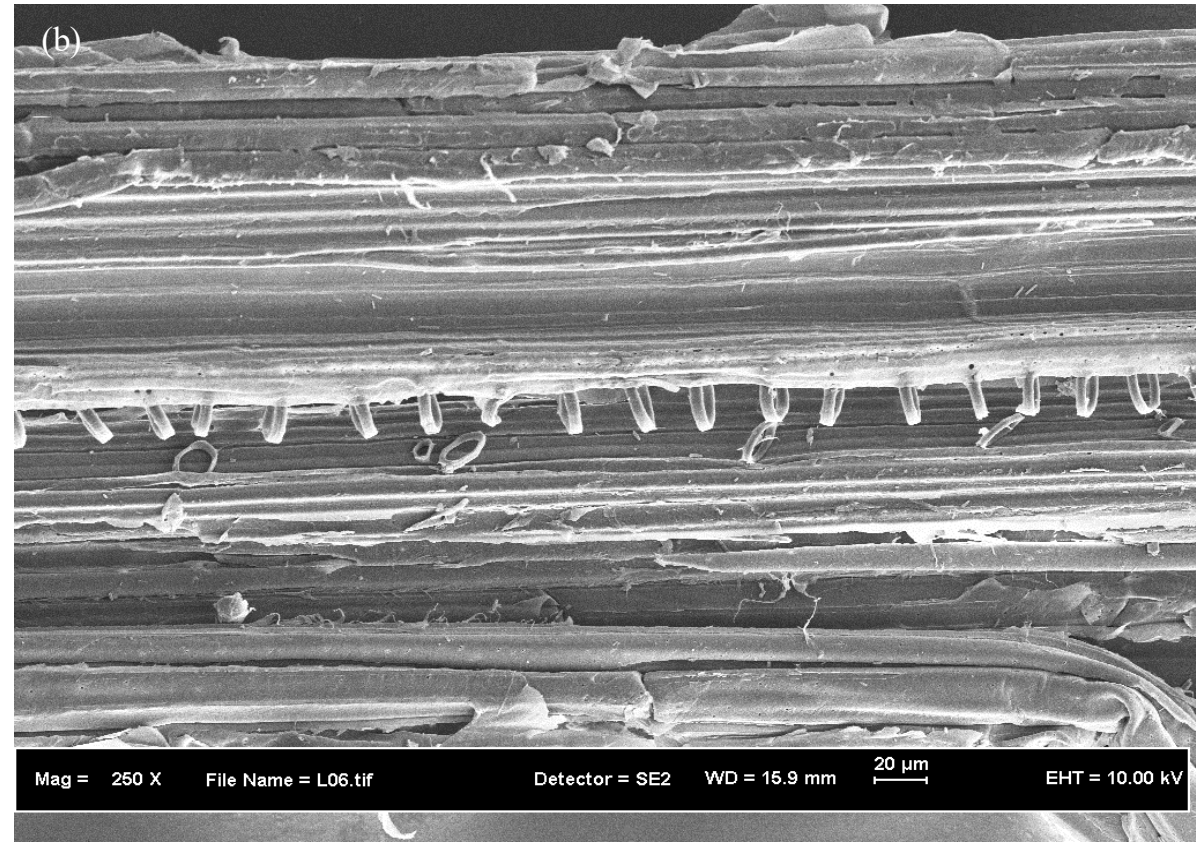

Fig. 4 - (b) Field Emission Scanning Electron micrographs of NaOH treated leave fibers

Additionally, the alkaline treated leave fibers and stem shown in Fig. 5 (a) and (b) reveal a compressed cellular structure for treated 4\% $\mathrm{NaOH}$ leave fibers and stem accordingly. Apparently, treatment destroys the cellular structure of the fibers; hence reduced the void content of the fibers and this can lead to lower water absorption. And thus, the cellulose chains are always in a condition of constraint. After alkaline treatment, the layer of hemicellulose was removed and thereby removed the internal constraint. A denser and closer packing cellulose fibril has been formed and thus improved the fiber strength as well as its tensile properties in the making of paper sheets. Nevertheless, the size of 
the lumen and the cell wall thickness of the leave fibers could affect the rigidity and flexural strength of the paper sheet. Larger lumen and thinner wall fibers tend to flatten to a long and narrow strip of fabric form during pulping, giving good contact between the fibers and consequently having higher strength characteristics.

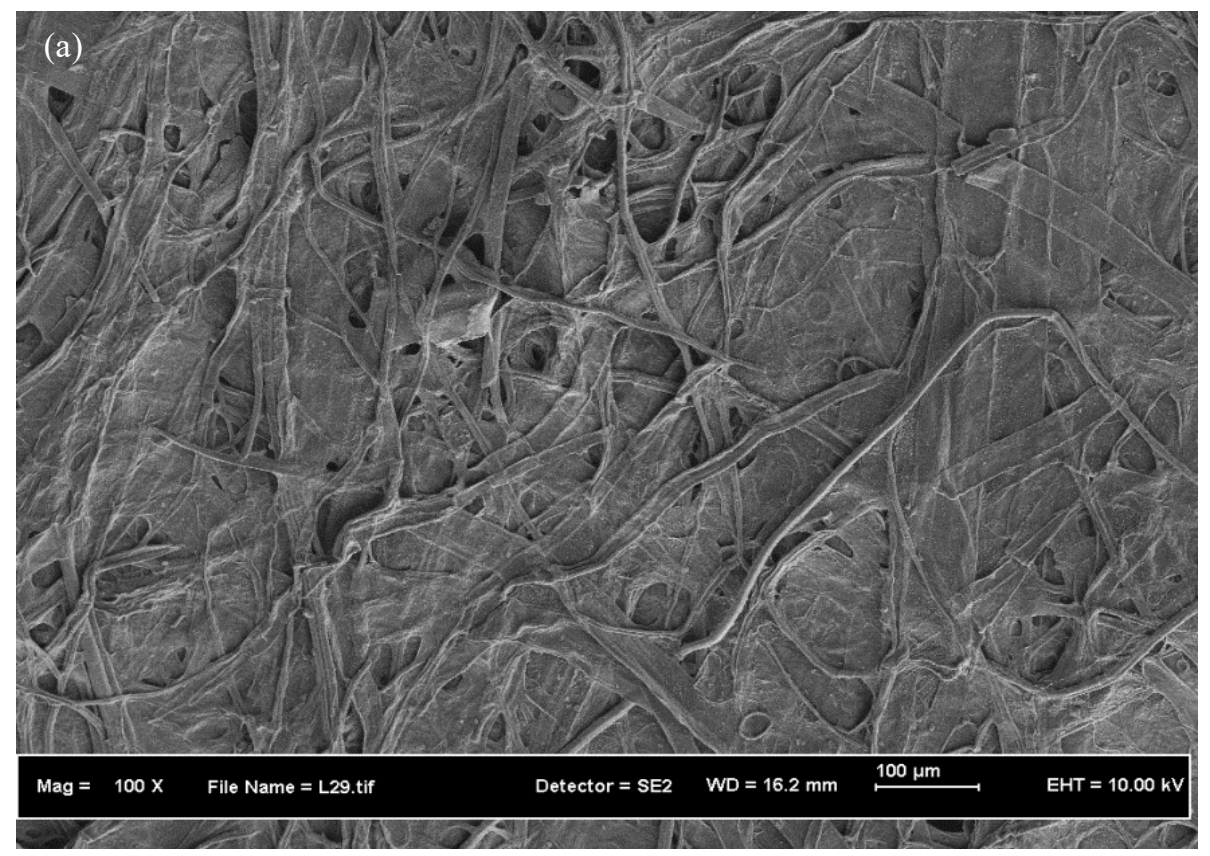

Fig. 5 - (a) Field Emission Scanning Electron micrographs of treated 4\% $\mathrm{NaOH}$ leave fibers



Fig. 5 - (b) Field Emission Scanning Electron micrographs of treated 4\% $\mathrm{NaOH}$ stem

\section{Conclusion and Contribution}

The alkali treatment of fibers resulted from the insolubilization of hemicellulose leads to the reduction of its content in the fibers. The treated $4 \% \mathrm{NaOH}$ leave fiber samples were indicated to be significant for the replacement of wood-based paper due to their lower moisture uptake, better shear strength, higher tensile stress and uniformly 
distribution of fibers. Therefore, this study indicates the feasibility of utilizing Napier grass as an alternative resource for non-wood based paper making.

\section{Acknowledgement}

The authors would like to acknowledge the Politeknik Kota Kinabalu, Department of Mechanical Engineering Kota Kinabalu Sabah, Universiti Teknologi Malaysia, Department of Polymer Engineering Skudai Johor and School of Engineering, Taylor's University, Subang Jaya Selangor.

\section{References}

[1] O. L. M. Kamoga, J. B. Kirabira, J. K. Byaruhanga, R. D. Godiyal, and K. Anupam, "Characterisation and evaluation of pulp and paper from selected Ugandan grasses for the paper industry," Cellul. Chem. Technol., vol. 50, no. 2, pp. 275-284, 2016.

[2] Y. Jiang et al., "Papermaking potential of Pennisetum hybridum fiber after fertilizing treatment with municipal sewage sludge," J. Clean. Prod., vol. 208, pp. 889-896, 2019.

[3] K. Obi Reddy, C. Uma Maheswari, M. Shukla, and E. Muzenda, "Preparation, Chemical Composition, Characterization, and Properties of Napier Grass Paper Sheets," Sep. Sci. Technol., vol. 49, no. 10, pp. 15271534, 2014.

[4] Z. Daud, M. Z. M. Hatta, A. S. M. Kassim, H. Awang, and A. M. Aripin, "Exploring of agro-waste (pineapple leaf, corn stalk, and napier grass) by chemical composition and morphological study," BioResources, vol. 9, no. 1 , pp. 872-880, 2014.

[5] M. J. M. Ridzuan, M. S. Abdul Majid, A. Khasri, K. S. Basaruddin, and A. G. Gibson, "Effect of moisture exposure and elevated temperatures on impact response of Pennisetum purpureum/glass-reinforced epoxy (PGRE) hybrid composites," Compos. Part B Eng., vol. 160, no. October 2018, pp. 84-93, 2019.

[6] I. C. Madakadze, T. M. Masamvu, T. Radiotis, J. Li, and D. L. Smith, "Evaluation of pulp and paper making characteristics of elephant grass (Pennisetum purpureum Schum) and switchgrass (Panicum virgatum L.)," African J. Environ. Sci. Technol., vol. 4, no. July, pp. 465-470, 2010.

[7] N. S. A. Hisham, S. I. A. Razak, N. H. M. Nayan, and W. A. W. A. Rahman, "Influence of polyaniline coated kenaf fiber on kenaf paper sheet," MATEC Web Conf., vol. 27, pp. 5-7, 2015.

[8] K. O. Reddy, C. U. Maheswari, M. Shukla, and A. V. Rajulu, "Chemical composition and structural characterization of Napier grass fibers," Mater. Lett., vol. 67, no. 1, pp. 35-38, 2012.

[9] R. Narinthorn, W. Choorit, and Y. Chisti, "Alkaline and fungal pretreatments for improving methane potential of Napier grass," Biomass and Bioenergy, vol. 127, no. January, p. 105262, 2019.

[10] M. Haameem, M. S. Abdul Majid, M. Afendi, H. F. A. Marzuki, I. Fahmi, and A. G. Gibson, "Mechanical properties of Napier grass fibre/polyester composites," Compos. Struct., vol. 136, pp. 1-10, 2016.

[11] S. Premaratne and G. G. C. Premalal, "Hybrid Napier (Pennisetum perpureum X Pennisetum americarnum) VAR. CO-3: a resourceful fodder grass for dairy development in Sri Lanka," J. Agric. Sci., vol. 2, no. 1, p. 22 , 2006.

[12] R. W. Hurter and P. Eng, "Will Nonwoods Become an Important Fiber Resource for North America ?," World Wood Summit Proc., no. 1, 1998.

[13] A. Gautam, A. Kumar, and D. Dutt, "Effects of Ethanol Addition and Biological Pretreatment on Soda Pulping of Eulaliopsis binata," J. Biomater. Nanobiotechnol., vol. 07, no. 02, pp. 78-90, 2016.

[14] T. Senthil Muthu Kumar, N. Rajini, K. Obi Reddy, A. Varada Rajulu, S. Siengchin, and N. Ayrilmis, “Allcellulose composite films with cellulose matrix and Napier grass cellulose fibril fillers," Int. J. Biol. Macromol., vol. 112, pp. 1310-1315, 2018.

[15] E. Abraham et al., "Extraction of nanocellulose fibrils from lignocellulosic fibres: A novel approach," Carbohydr. Polym., vol. 86, no. 4, pp. 1468-1475, 2011. 